\title{
Comparative Study of Functional Outcome Between Proximal Humeral Nailing and Philos Plating for Neer's Type Two-, Three-, Four - Proximal Humeral Fractures
}

ISSN: 2576-8875

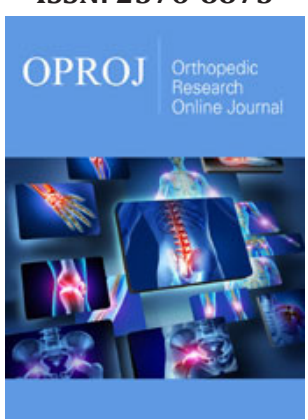

${ }^{* 1}$ Corresponding author: Navya Tez, Junior Resident of Orthopedics, Guntur Medical College, Guntur, Andhra Pradesh, India

Submission: 梅 October 11, 2019

Published: 制October 16, 2019

Volume 6 - Issue 1

How to cite this article: Lokesh Sharma D, Madhava Reddy M, Navya Tez. Comparative Study of Functional Outcome Between Proximal Humeral Nailing and Philos Plating for Neer's Type Two-, Three-, Four - Proximal Humeral Fractures. Ortho Res Online J. 6(1). OPROJ.000629.2019. DOI: $10.31031 /$ OPROJ.2019.06.000629

Copyright@: Navya Tez, This article is distributed under the terms of the Creative Commons Attribution 4.0 International License, which permits unrestricted use and redistribution provided that the original author and source are credited.
Lokesh Sharma D, Madhava Reddy M and Navya Tez*

Department of Orthopedics, India

\begin{abstract}
Background: Proximal humeral nail and PHILOS plate fixation for the proximal humeral fractures offers good anatomic fracture reduction and stable primary fixation to ensure rapid fracture healing and immediate post-operative functional therapy without prolonged immobilization.
\end{abstract}

Objectives: To assess and compare the fracture union and the functional outcome of proximal humerus fractures using proximal humeral nail and PHILOS plate.

Materials and methods: A comparative prospective study was conducted at Guntur Medical College from October 2016 to October 2018. In this study we have included a total of 34 patients randomly selected as 15 cases for PHN group and 19 cases included in PHILOS group. The follow-up period was 12 months.

Results: In our study, majority were males (73.5\%) and most common mode of injury (73.5\%) was RTA with Neer's 3- part (44.1\%) is the most common type of fracture. out of 15 cases in the PHN group 5 cases (33.3\%) had Excellent, 7 cases (46.7\%) had Satisfactory, 1 case (6.7\%) had satisfactory and 2 cases (13.3\%) had Failure outcome. Out of 19 cases of PHILOS group, 3 cases (15.8\%) had Excellent, 14 cases (73.7\%) had satisfactory, 2 cases (13.3\%) had Unsatisfactory outcome and there were Failure cases according to Neer's criteria. There was no significant difference ( $p$ value $>0.05$ ) between the two groups.

Conclusion: Both the treatment options are effective in treating the proximal fractures and there was no significant difference between functional outcome between the two groups at 1-year follow-up.

Keywords: Proximal humeral fractures; PHN; PHILOS plate

Introduction

Proximal humerus fractures are becoming increasingly prevalent with rapidly expanding population, accounting for $6 \%$ of all fractures in the human body [1]. Most of the humeral fractures can be treated with conservative methods, including a period of immobilization in a sling, followed by functional exercises [2]. However, to achieve satisfactory functional outcomes, displaced and unstable fractures are treated surgically [3]. It was reported that such fractures account for approximately $12.6 \%$ of all proximal humeral fractures [4]. Many surgical procedures proved to be effective including locking plates, intramedullary nails, hemiarthroplasty and reverse total shoulder replacement [5-7]. Handoll [8] reviewed two studies that compared the locking plate and intramedullary nail. Several studies [6,9-15] have focused on locking plate and intramedullary nail for treatment of displaced two-, threeand four-part proximal humeral fractures. However, an integral body of evidence was urgent regarding the outcomes of locking plate and intramedullary nail treatment for proximal humeral fractures because of advances in the methods of internal fixation devices.

The goals of surgery are to obtain anatomic fracture reduction and stable primary fixation to ensure rapid fracture healing and immediate post-operative functional therapy without prolonged immobilization [9,16]. For both devices, implant -related complications such as nail or plate impingement and secondary screw perforation have been reported $[9,17,18]$.

The objective of this prospective observational study is to compare plate versus nail fixation of two-,three- and four- part proximal humeral fractures regarding surgical time for 
intraoperative fluoroscopy, functional, functional assessment using Neer's score and radiological assessment of quality of reduction, presence of hard ware-related complications and rate of local complications.

\section{Materials and Methods}

A prospective study was conducted in Guntur Medical College, Guntur from October 2016 to October 2018. This study included the patients with fracture of proximal humerus requiring surgical interventions, after taking their consent, were analyzed clinically and radiologically. All the patients selected for the study were evaluated as per the history \& mode of injury, necessary clinical and laboratory investigations.

A total of 34 cases have been studied without any sampling procedure.

1. 15 patients underwent proximal humeral nailing

2. 19 underwent PHILOS plating.

The pre-operative and immediate post-operative X-ray were evaluated. The patients were evaluated clinically and radiologically in their subsequent follow-up every 6 weeks till fracture union and at 1 year after surgery.

The comparative studies of patients aged between 18 to 65 years with Neer's two, three and four part proximal humeral fractures allocated into two treatment groups; [a] PHN group and [b] PHILOS group were included for the study. Patients aged less than 17 years, pathological fractures and open fractures, periprosthetic fractures, patients medically unfit for surgery were excluded from the study.

A careful history was elicited from the patients and /or attendants to reveal the mechanism of injury and the severity of trauma. The patients were then assessed clinically to evaluate their general condition and the local injury. In general condition, the vital signs were recorded. Care was taken to detect shock and any associated injuries. Local examination of the injured arm, revealed the attitude of the limb to be flexed at the elbow, adducted at the shoulder and supported with the other hand at the elbow. Swelling, deformity, loss of function and nerve injury were looked for and noted. Palpation revealed tenderness, abnormal mobility, crepitus and of the affected shoulder. Distal vascularity was assessed by radial artery pulsations, capillary refilling, pallor and paresthesia at fingertips.

Standard radiography of the shoulder, such as anteroposterior and axillary views, were obtained. The shoulder and elbow joints were included in each view. The limb was immobilized in a U-Slab with sling. Injectable analgesics were given. The operative procedure and its advantages were explained in detail to each patient and an informed consent was obtained. The patients posted for surgery were subjected to routine investigations (Figure 1-4).

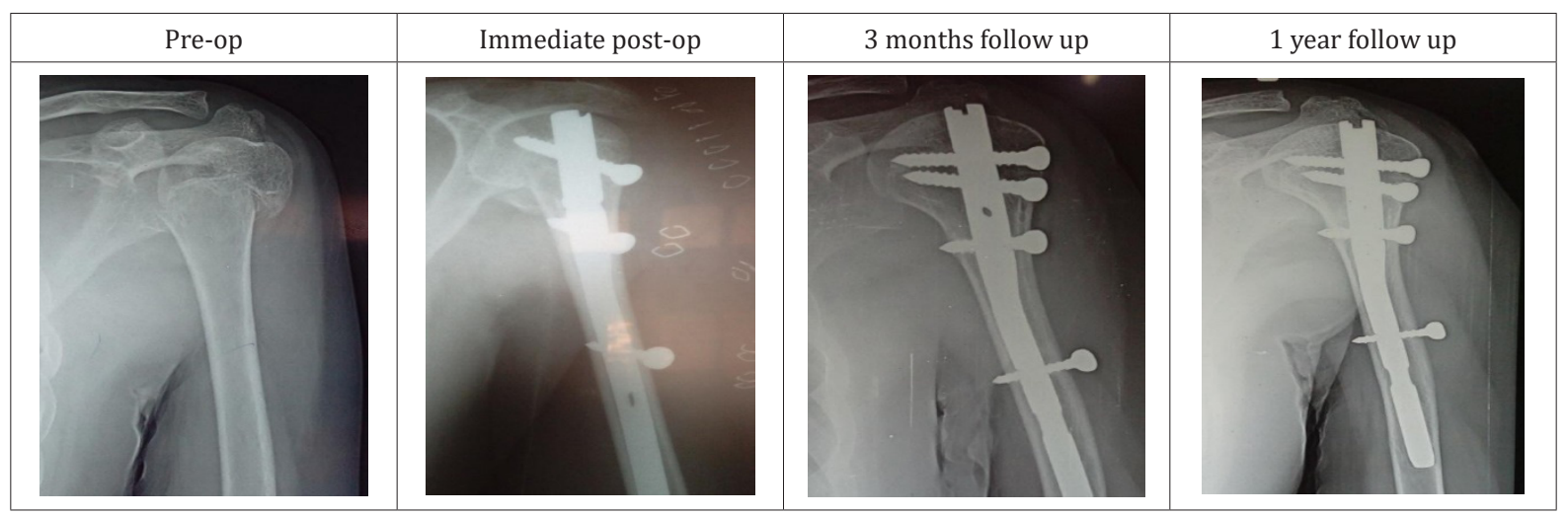

Figure 1: Radiographs of fracture of surgical neck of humerus with PHN.

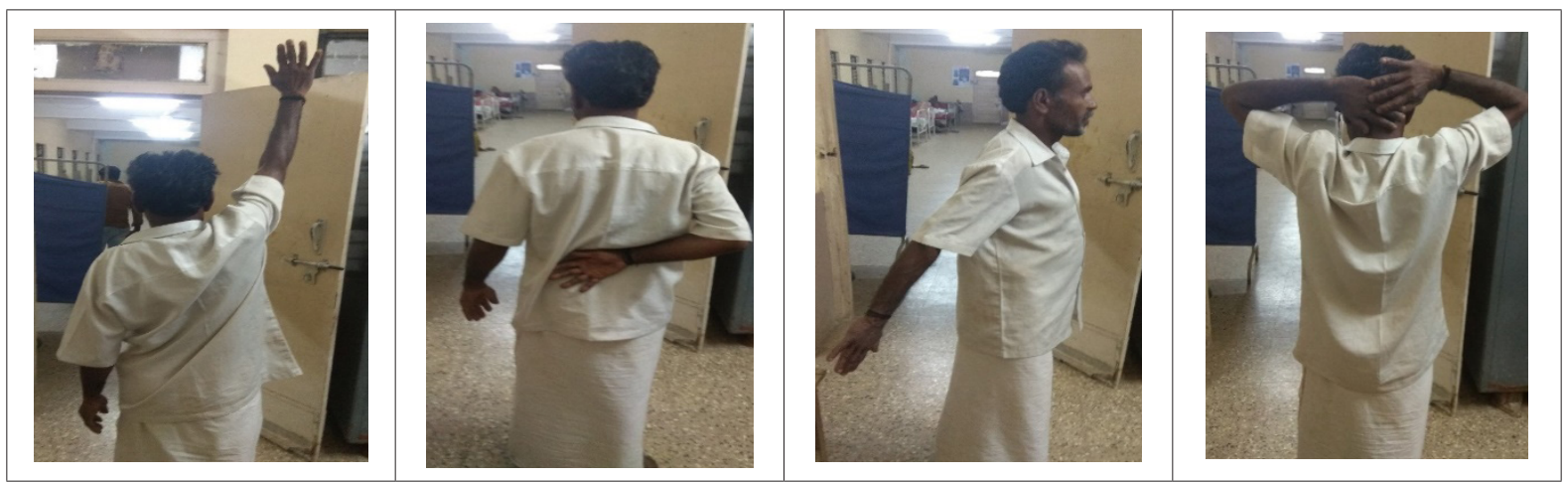

Figure 2: Range of movements with PHN. 


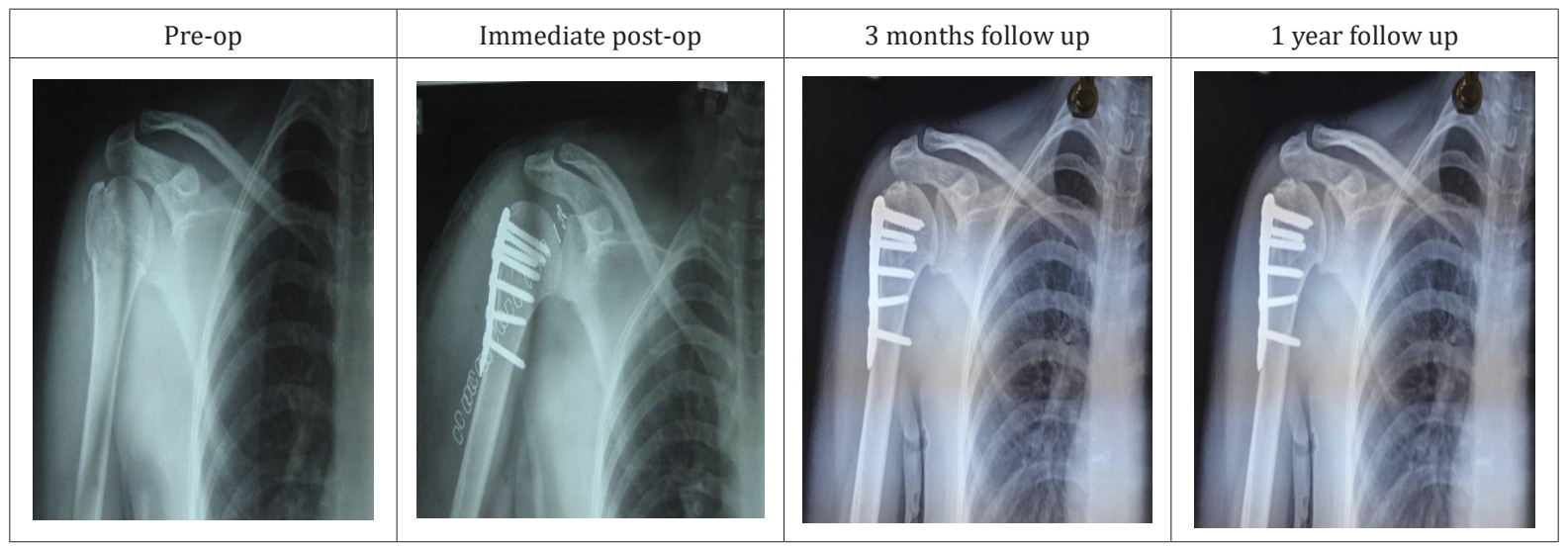

Figure 3: Radiographs of fracture of surgical neck of humerus with PHILOS.

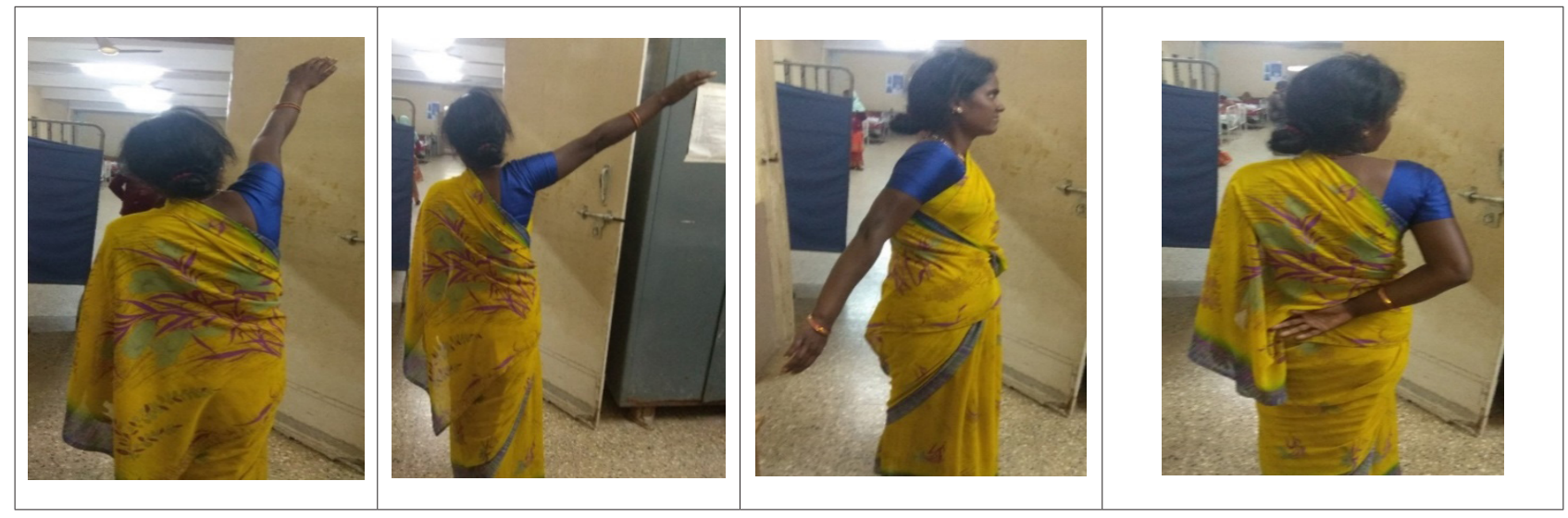

Figure 4: Range of movements with PHILOS.

\section{Results}

This prospective study was conducted at Guntur Medical College, Guntur for a period of two years from October 2016 to October 2018. A total of 34 cases have been studied without any sampling procedure. A total of 15 patients (44.12\%) underwent proximal humeral and 19 patients (55.88\%) underwent PHILOS plating.

\section{Age distribution among two groups}

The most common age group in our series was 31-40 \& 5160 with an overall average age of $42.15 \pm 11.15$ yrs. Average age for PHN Group is $36.20 \pm 9.22$ and for PHILOS group is $46.84 \pm 10.45 \mathrm{yrs}$. Here the p value $=0.004$ and was significant $($ Table 1 ).

Table 1: Comparison of age among PHN and PHILOS Group ( $\mathrm{N}=34)$.

\begin{tabular}{|c|c|c|c|}
\hline \multirow[b]{2}{*}{ Age (in years) } & \multicolumn{2}{|c|}{ Groups } & \multirow[b]{2}{*}{ Total } \\
\hline & $\begin{array}{c}\text { PHN } \\
(n=15) n(\%)\end{array}$ & $\begin{array}{c}\text { PHILOS } \\
(n=19) \text { n (\%) }\end{array}$ & \\
\hline$\leq 30$ & $5(33.3)$ & $2(10.5)$ & $7(20.6)$ \\
\hline $31-40$ & $6(40.0)$ & $4(21.1)$ & $10(29.4)$ \\
\hline $41-50$ & $3(20.0)$ & $4(21.1)$ & $7(20.6)$ \\
\hline $51-60$ & $1(6.7)$ & $9(47.4)$ & $10(29.4)$ \\
\hline \multicolumn{4}{|c|}{ Chi-square test (7.867), df (3) p Value $=0.05$, Not significant } \\
\hline Mean & 36.20 & 46.84 & 42.15 \\
\hline SD & 9.22 & 10.45 & 11.15 \\
\hline \multicolumn{4}{|c|}{ Student $t$ Test, $\mathrm{P}$ Value $=0.004$, Significant } \\
\hline
\end{tabular}




\section{Gender distribution}

In our study, 19 were male patients and 9 were female patients out of 34 patients and the $p$ value $=0.447$ which was not significant (Table 2).

\section{Mode of Injury}

In our study, 25 cases are of RTA and 9 cases of self-fall as a node of injury out of 34 cases and $p$ value $=0.447$ which was not significant. Type of fractures according to Neer's classification (Table 3).

Table 2: Comparison of Gender among PHN and PHILOS group ( $\mathrm{N}=34)$.

\begin{tabular}{|c|c|c|c|}
\hline \multirow{2}{*}{ Gender } & \multicolumn{2}{|c|}{ Group } & PHILOS \\
\cline { 2 - 4 } & PHN & (n=19) $\mathbf{n}(\%)$ & Total \\
\hline Male & $(\mathbf{n = 1 5 )} \mathbf{n}(\mathbf{\%})$ & $13(68.4)$ & $25(73.5)$ \\
\hline Female & $12(80)$ & $6(31.6)$ & $9(26.5)$ \\
\hline
\end{tabular}

Table 3: Type of fractures according to Neer's classification.

\begin{tabular}{|c|c|c|c|}
\hline Type of Fracture & PHN & PHILOS & Total \\
\hline $2 \mathrm{P}$ & $\mathbf{n}(\%)$ & $4(21.1)$ & $13(38.2)$ \\
\hline $3 \mathrm{P}$ & $4(26.7)$ & $11(57.9)$ & $15(44.1)$ \\
\hline $4 \mathrm{P} \quad$ & $2(13.3)$ & $4(21.1)$ & $6(17.6)$ \\
\hline \multicolumn{2}{|r|}{ Chi-square test (5.461), df (2), p Value $=0.065$, Not significant } \\
\hline
\end{tabular}

\section{Functional outcome among PHN and PHILOS Group}

In our study, 8 cases had excellent outcome, 21 cases had satisfactory outcome, 3 cases had unsatisfactory outcome and 2 cases had failure outcome out of 34 cases and p value was 0.190 which is not significant (Table 4).

Comparison of NEER scores among PHN and PHILOS Group: at 6 weeks, 3 months and 1 year ( Table 5).

Table 4: Functional outcome among PHN and PHILOS group (N=34).

\begin{tabular}{|c|c|c|c|}
\hline Functional Outcome & PHN & PHILOS & n (\%) \\
\hline Excellent & $\mathbf{n}(\%)$ & $3(15.8)$ & $8(23.5)$ \\
\hline Satisfactory & $5(33.3)$ & $14(73.7)$ & $21(61.8)$ \\
\hline Unsatisfactory & $7(46.7)$ & $2(10.5)$ & $3(8.8)$ \\
\hline Failure & $1(6.7)$ & $0(0)$ & $2(5.9)$ \\
\hline
\end{tabular}

Table 5: Comparison of NEER scores among PHN and PHILOS Group: at 6 weeks, 3 months and 1 year (N=34).

\begin{tabular}{|c|c|c|c|c|}
\hline & Group & Mean \pm SD & t-value & p-value \\
\hline \multirow{3}{*}{6 weeks } & PHN & $54.00 \pm 5.81$ & -2.077 & 0.046 \\
\cline { 2 - 5 } & PHILOS & $58.33 \pm 6.32$ & & \\
\hline \multirow{3}{*}{3 months } & PHN & $73.16 \pm 4.16$ & 0.500 & 0.621 \\
\cline { 2 - 5 } & PHILOS & $72.00 \pm 8.97$ & & 0.027 \\
\hline \multirow{2}{*}{1 year } & PHN & $82.74 \pm 4.76$ & 0.978 \\
\hline
\end{tabular}


In our study, there was significant difference between the PHN and PHILOS only at 6 weeks and $p$ value $=0.046$. But there was no significant difference in mean scores between the two groups at 3 months $(\mathrm{p}=0.621)$ and 1 year $(\mathrm{p}=0.978)$.

\section{Complications among PHN and PHILOS Group}

In our study, complications such as, infection was seen in 2 cases of PHILOS group and in 1 case of PHN group, varus malunion was seen 2 cases of PHILOS group and 2 cases of PHN group, glenohumeral protrusion was seen in 1 case of PHN group, shoulder impingement was seen in 4 cases of PHN group, and screw backout was seen in 2 cases of PHILOS group, and greater tuberosity nonunion was seen in 1 case of PHN and there were no nerve injuries in both the groups and p value was not significant (Table 6).

Table 6: Distribution of complications among both groups.

\begin{tabular}{|c|c|c|c|c|}
\hline Complications & $\begin{array}{l}\text { PHN } \\
\text { n (\%) }\end{array}$ & $\begin{array}{l}\text { PHILOS } \\
\text { n (\%) }\end{array}$ & $\begin{array}{c}\text { Chi-Square } \\
\text { (df) }\end{array}$ & $P$ value \\
\hline $\begin{array}{l}\text { Infections } \\
\text { Present } \\
\text { Absent }\end{array}$ & $\begin{array}{c}1(6.7) \\
14(93.3)\end{array}$ & $\begin{array}{l}2(10.5) \\
17(89.5)\end{array}$ & $\begin{array}{c}0.159 \\
\text { (1) }\end{array}$ & 0.694 \\
\hline $\begin{array}{c}\text { Varus malunion } \\
\text { Present } \\
\text { Absent } \\
\end{array}$ & $\begin{array}{l}2(13.3) \\
13(86.7)\end{array}$ & $\begin{array}{l}2(10.5) \\
17(89.5)\end{array}$ & $\begin{array}{c}0.064 \\
(1) \\
\end{array}$ & 0.801 \\
\hline $\begin{array}{l}\text { Impingement } \\
\text { Present } \\
\text { Absent }\end{array}$ & $\begin{array}{r}4(26.67) \\
11(73.33) \\
\end{array}$ & $\begin{array}{c}0 \\
19(100)\end{array}$ & $\begin{array}{c}3.286 \\
(1) \\
\end{array}$ & 0.069 \\
\hline $\begin{array}{c}\text { Screw Backout } \\
\text { Present } \\
\text { Absent }\end{array}$ & $\begin{array}{c}0 \\
15(100)\end{array}$ & $\begin{array}{l}2(10.5) \\
17(89.5)\end{array}$ & $\begin{array}{l}1.678 \\
(1)\end{array}$ & 0.195 \\
\hline $\begin{array}{c}\text { Glenohumeral protru } \\
\text { Present } \\
\text { Absent }\end{array}$ & $\begin{array}{c}1(6.7) \\
14(93.3)\end{array}$ & $\begin{array}{c}0 \\
19(100)\end{array}$ & $\begin{array}{l}1.305 \\
(1) \\
\end{array}$ & 0.253 \\
\hline $\begin{array}{l}\text { Non union } \\
\text { Present } \\
\text { Absent }\end{array}$ & $\begin{array}{c}1(6.7) \\
14(93.3)\end{array}$ & $\begin{array}{c}0 \\
19(100)\end{array}$ & $\begin{array}{c}1.305 \\
(1)\end{array}$ & 0.253 \\
\hline $\begin{array}{c}\text { Nerve injuries } \\
\text { Present } \\
\text { Absent }\end{array}$ & $\begin{array}{c}0 \\
15(100)\end{array}$ & $\begin{array}{c}0 \\
19(100)\end{array}$ & - & - \\
\hline
\end{tabular}

Type of fracture with functional outcome among PHN and PHILOS Group

In our study, 4 cases had excellent outcome, 5 cases had satisfactory outcome in PHN group and 1 case had excellent outcome, 3 cases had satisfactory outcome in PHILOS group among patients diagnosed with Neer's 2-part fracture.1 case had excellent outcome, 1 case had satisfactory outcome, 1 case had unsatisfactory outcome, 1 case failure outcome in PHN group and 2 case had excellent outcome, 8 cases had satisfactory outcome , 1 case had unsatisfactory outcome in PHILOS group among patients diagnosed with Neer's 3-part fracture and 1 case had satisfactory outcome, and 1 case had failure outcome in PHN group and 3 cases had satisfactory outcome, 1 case had unsatisfactory outcome in PHILOS group among patients diagnosed with Neer's 4-part fracture and the p value was not significant (Table 7; Figure $5 \& 6$ ). 
Table 7: Type of fractures with functional outcome among both groups.

\begin{tabular}{|c|c|c|c|c|c|c|}
\hline \multirow[t]{2}{*}{ Functional Outcome } & \multicolumn{3}{|c|}{$\begin{array}{c}\text { PHN } \\
\text { n (\%) }\end{array}$} & \multicolumn{3}{|c|}{$\begin{array}{l}\text { PHILOS } \\
\text { n (\%) }\end{array}$} \\
\hline & $2 P$ & $3 P$ & $4 P$ & $2 P$ & $3 P$ & 4P \\
\hline Excellent & $4(44.44)$ & $1(25)$ & 0 & $1(25)$ & $2(18.18)$ & 0 \\
\hline Satisfactory & $5(55.56)$ & $1(25)$ & $1(50)$ & $3(75)$ & $8(72.72)$ & $3(75)$ \\
\hline Unsatisfactory & $0(0)$ & $1(25)$ & $0(0)$ & 0 & $1(9.09)$ & $1(25)$ \\
\hline Failure & $0(0)$ & $1(25)$ & $1(50)$ & 0 & 0 & 0 \\
\hline \multicolumn{4}{|c|}{ Chi-square test (8.018), df (6), $p$ Value $=0.237$, Not significant } & \multicolumn{3}{|c|}{ Chi-square test (2.128), df (4), p Value $=0.712$, Not significant } \\
\hline
\end{tabular}

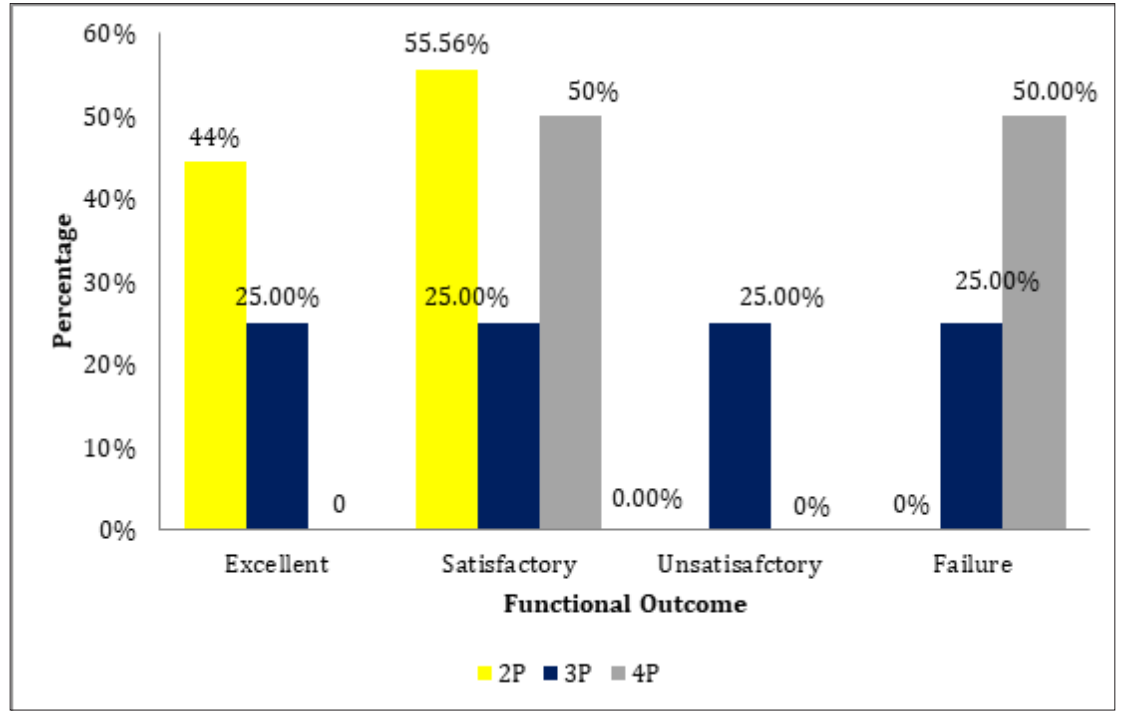

Figure 5: Type of Diagnosis with functional outcome among PHN Group $(n=15)$.

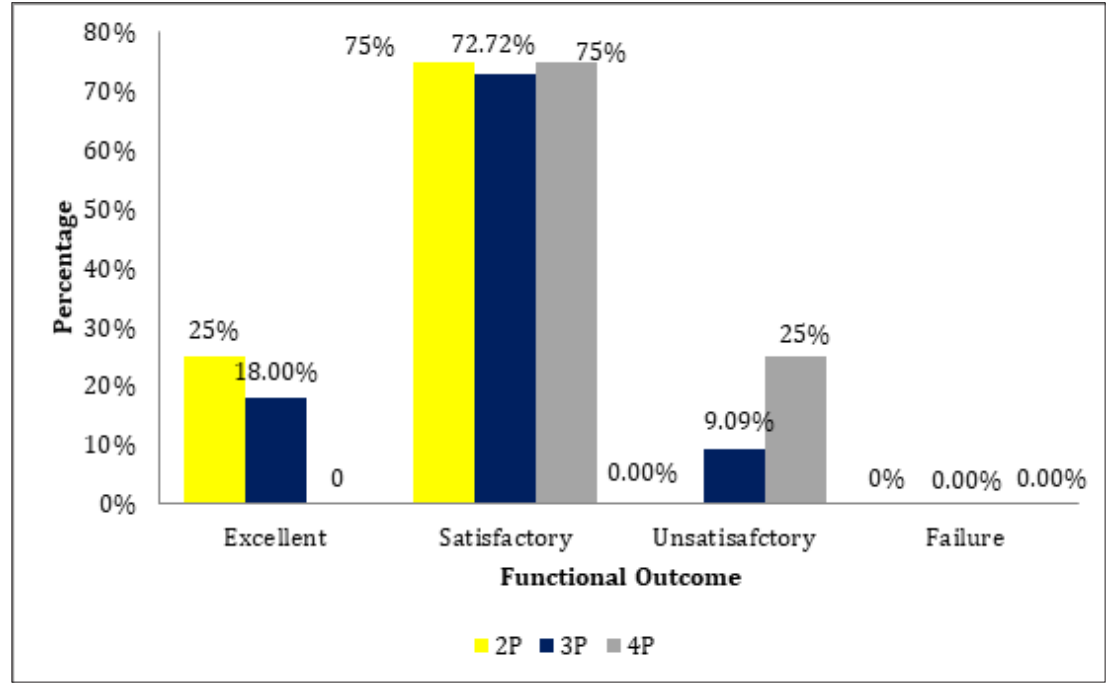

Figure 6: Type of Diagnosis with functional outcome among PHILOS Group (n=19).

\section{Discussion}

The treatment of proximal humerus fractures continues to evolve. While many of these injuries can be managed nonoperatively, a certain percentage require operative treatment. The appropriate treatment of proximal humerus fractures is predicated on the ability of the treating surgeon to identify the injury in a timely and accurate fashion and have a complete and thorough understanding of the fracture pattern. ${ }^{(7,8)}$ There are many factors to consider on an individual basis when an operative procedure is planned, including patient age, functional status, physic social factors, fracture pattern, displacement, associated injuries, remaining vascular supply to the articular fragment, and bone quality and finally the ability to tolerate postoperative rehabilitation [9-11]. 
Treatment options Currently range from non-operative treatment with physical therapy to fracture fixation using percutaneous, closed or open techniques to arthroplasty reconstructions. Majority of the proximal humerus fracture which are un-displaced can be treated conservatively. Even with development of newly designed locking plates and nails, treatment of displaced fracture or fracture dislocation is difficult. Many studies have shown that the displaced fracture of the proximal humerus have a poor functional prognosis when left untreated because of severe displacement of fragments $[12,13]$.

Closed reduction and internal fixation (CRIF) with an intramedullary nail (PHN) or Open reduction with internal fixation with PHILOS plate provides near anatomical reduction and stable fixation.

In proximal humerus fractures, proximal humerus nail offers excellent outcome with context to early joint mobilization and stable fixation of the fracture with limited soft tissue damage where as PHILOS plate osteosynthesis provides better rigid fixation and stability in osteoporotic and communited fractures and the possibility of bone grafting $[14,15]$.

The present study was undertaken to compare the functional outcome following closed reduction and internal fixation with PHN and Open reduction and internal fixation with PHILOS plate for Neer's 2-part ,3-part, 4-part fractures.

The present prospective study was conducted at Guntur Medical College, Guntur from October 2016 to October 2018. In this study we have included a total of 34 patients randomly selected as 15 cases for PHN group and 19 cases included in PHILOS group. This study is having a short term follow up of minimum of 12 months and hence its overall a preliminary assessment. We evaluated our results and compared them with those obtained by various other studies that have compared these two modalities of treatment and also with studies that have used various different modalities of treatment. Our analysis was as follows.

\section{Age distribution}

In this study, fractures of proximal humerus are seen commonly in middle aged adults ranging from 31-40 \& 51-60yrs group, with the mean age being $42.15 \pm 11.15$ with average age for PHN Group is $36.20 \pm 9.22$ and for PHILOS group is $46.84 \pm 10.45$ yrs.

\section{Sex distribution}

In this study, most of the patients were males 25 (73.5\%) and females were 9 (26.5\%). Male preponderance is more as compared to females due to the strenuous activities of males and also road traffic accidents being the more common mode of injury as well. The most common cause for female incidence is osteoporosis.

\section{Mode of injury}

In our study, most common cause of proximal humeral fracture was Road traffic accidents 25 cases (73.5\%) and the other cause was found to be self-fall.

\section{Type of fracture}

Of the 34 cases in this study, 13 cases (38.2\%) were Neer's 2-part fractures. 15 cases were found to be Neer's 3-part fractures (44.1\%). 6 cases were Neer's 4-part fractures and they were fixed with either modality of internal fixation selected randomly.

\section{Outcome}

In our study, out of 15 cases in the PHN group 5 cases (33.3\%) had Excellent outcome, 7 cases (46.7\%) had Satisfactory outcome, 1 case $(6.7 \%)$ had Unsatisfactory outcome and 2 cases (13.3\%) had Failure outcome. Out of 19 cases of PHILOS group, 3 cases (15.8\%) had Excellent outcome, 14 cases (73.7\%), 2 cases (13.3\%) had Unsatisfactory outcome and there were no Failure cases.

\section{Complications}

In our study, out of 15 cases of PHN group, 1 case(6.7\%) had surgical wound site infection which was treated with 5 days of antibiotics, $2(13.3 \%)$ cases had varus malunion 2 cases(13.3\%) had shoulder pain because of impingement, 1 case $(6.7 \%)$ had glenohumeral protrusion of the screw and 1 case had greater tuberosity malunion.

Out of 19 cases of PHILOS group ,2 cases (13.3\%) had surgical wound site infection which was treated by antibiotics. 2 cases (13.3\%) had varus malunion, 2 cases (13.3\%) had screw backout as complication.

Konrad et al. [14] have conducted a prospective study was to compare the clinical and radiological outcomes of plate versus nail fixation of 3-part fractures in 211 patients with proximal humeral fractures. Outcome measurements included pain, Constant and Murley and Neer's scores, and the occurrence of complications at 3, 6- and 12-months post-surgery. Throughout the 1year follow-up period there was no significant difference between the nail group compared with the plate group.

Xiandong et al. [19] have conducted a retrospective study to analyse the outcomes of proximal humeral fractures in 38 patients treated with locking plate (24 cases) and intramedullary nail ( 9 cases) from March 2012 to May 2013. And all the patients were followed up for 9 to 23 months (mean 16.1 months). There were significant differences in the length of incision, operation time and complication rate between two groups $(t=8.857,5.323$, $2.460, \mathrm{p}<0.05$ ). The incidence of complications in the locking plate group was low, and in the interlocking intramedullary nail group patients had small incision and short operation time. There was no significant difference in neck dry angle and fracture healing time between the two groups $(\mathrm{t}=0.548,0.459, \mathrm{p}>0.05)$. The pre-existing range, Constant-Murley shoulder function score, and excellent rate of patients with the locking plate group were higher than those of interlocking intramedullary nail group, but the difference was not statistically significant $(\mathrm{t}=1.470,0.905,0.133, \mathrm{p}>0.05)$ (Table 8 ). 
Table 8:

\begin{tabular}{|c|c|c|c|c|c|c|c|c|}
\hline Study & $\begin{array}{l}\text { No. of Pa- } \\
\text { tients (IMN/ } \\
\text { LP) }\end{array}$ & $\begin{array}{c}\% \text { of } \\
\text { Females } \\
\text { (IMN/LP) }\end{array}$ & $\begin{array}{l}\text { Neers Classifica- } \\
\text { tion (IMN/LP) }\end{array}$ & $\begin{array}{c}\text { Mean Age(Y) (IMN/ } \\
\text { LP) }\end{array}$ & $\begin{array}{l}\text { Follow Up } \\
\text { (Months) } \\
\text { (IMN/LP) }\end{array}$ & $\begin{array}{l}\text { Study As- } \\
\text { sessment }\end{array}$ & $\begin{array}{l}\text { Score } \\
\text { [IMN] }\end{array}$ & Score $[\mathrm{LP}]$ \\
\hline $\begin{array}{l}\text { Gradl et al. } \\
\text { [9] }\end{array}$ & $76 / 76$ & $71 / 71$ & $2 \mathrm{P}-52,3 \mathrm{P}-60,4 \mathrm{P}-40$ & $63 \pm 16$ & $12.8 \pm 0.4$ & CS & $77 \%$ & $81 \%$ \\
\hline $\begin{array}{l}\text { Matziolis et } \\
\text { al. [10] }\end{array}$ & $11 / 11$ & $64 / 642$ & $2 \mathrm{P}-22$ & $56 \pm 17 / 55 \pm 17$ & 36 & CS & $78 \%$ & $83 \%$ \\
\hline $\begin{array}{l}\text { Boudard et } \\
\text { al. [20] }\end{array}$ & $32 / 35$ & $59 / 40$ & $\begin{array}{c}3 \mathrm{P}-21,4 \mathrm{P}-9 / 3 \mathrm{P}- \\
21,4 \mathrm{P}-12\end{array}$ & $64 \pm 16 / 50 \pm 18$ & 12 & Mean CS & $60.6 \%$ & $59.7 \%$ \\
\hline $\begin{array}{l}\text { Gracitelli et } \\
\text { al. [21] }\end{array}$ & $32 / 33$ & $69 / 76$ & $\begin{array}{c}2 \mathrm{P}-16,3 \mathrm{P}-16, / 2 \mathrm{P}- \\
16,3 \mathrm{P}-17\end{array}$ & $65 \pm 9 / 66 \pm 8$ & 12 & CS & 70.3 & 71.5 \\
\hline $\begin{array}{l}\text { Gadea et al. } \\
{[22]}\end{array}$ & $46 / 46$ & $54 / 53$ & $4 \mathrm{P}-107$ & $64 / 57$ & $41 / 42$ & CS, N's & $77 \%$ & $81 \%$ \\
\hline $\begin{array}{c}\text { Cheng et al. } \\
\text { [23] }\end{array}$ & $54 / 54$ & $52 / 56$ & $\begin{array}{c}3 \mathrm{P}-36,4 \mathrm{P}-18 / 3 \mathrm{P}- \\
32,4 \mathrm{P}-22\end{array}$ & $54 \pm 13 / 56 \pm 13$ & 14 & CS & $85.2 \pm 13.5$ & $87.4 \pm 10.4$ \\
\hline $\begin{array}{l}\text { Present } \\
\text { study }\end{array}$ & $15 / 19$ & $20 / 31$ & $\begin{array}{c}2 \mathrm{P}-9,3 \mathrm{P}-4,4 \mathrm{P}-2 / 2 \mathrm{P}- \\
4,3 \mathrm{P}-11,4 \mathrm{P}-4\end{array}$ & $\begin{array}{c}36.20 \\
\pm 9.22 / 46.84 \pm 10.45\end{array}$ & 12 & N's score & $82.74 \pm 4.1$ & $\begin{array}{l}82.67 \\
\pm 9.67\end{array}$ \\
\hline
\end{tabular}

In our study, the excellent outcomes were seen in 5 cases $(33.3 \%)$ and satisfactory outcomes were seen in 7 cases $(46.7 \%)$ out of 15 cases in the PHN group. And excellent functional outcomes were seen in 3 cases (15.8\%) and satisfactory outcomes were seen 14 cases $(73.7 \%)$ out of 19 cases of PHILOS group. The results are comparable to other studies with respect to functional outcomes, and complications of proximal humerus fractures [9,10,20-23].

\section{Conclusion}

We conclude that there was no statistical significant difference between functional outcome in the proximal humeral fractures that were treated with PHN and PHILOS plate at 3 months and 1-year follow-up though there is a significant difference in the functional outcome at 6 weeks follow-up.

The choice of implant for proximal humeral fractures depends on the surgeon's expertise to manage the fracture as every fracture has its own orientation and need for reduction and to provide an early mobilization and good clinical \& functional outcome to the patient.

\section{References}

1. Court-brown CM, Caesar B (2006) Epidemiology of adult fractures: a review. Injury 37(8): 691-697.

2. Handoll HH, Ollivere BJ (2010) Interventions for treating proximal humeral fractures in adults. The Cochrane database of systematic reviews (11): CD000434.

3. Murray IR, Amin AK, White TO, Robinson CM (2011) Proximal humeral fractures: current concepts in classification, treatment and outcomes. J Bone Joint Surg Am 93(1): 1-11.

4. Court-Brown CM, Garg A, McQueen MM (2001) The epidemiology of proximal fractures. Acta Orthopaedica 72: 365-371.

5. Maier D, Jaeger M, Izadpanah K, Storhm PC, Suedkamp NP (2014) Proximal humeral fracture treatment in adults. J Bone Joint Surg Am 96: 2512-2561.

6. Zhu Y, Lu Y, Shen J, Zhang J, Jiang C (2011) Locking intramedullary nails and locking plates in the treatment of two part proximal humeral surgical neck fractures: a prospective randomised trial with a minimum of three years of follow- up. J Bone Joint Surg Am 93(2): 159-168.
7. Mao Z, Zhang L, Zeng X, Chen S, Liu D, et al. (2014) Operative versus non operative treatment in complex proximal humeral fractures. Orthopaedics 37: e410-419.

8. Handoll H, Ollivere BJ, Rollins KE (2012) Interventions for treating proximal humeral fractures in adults. The Cochrane database of systematic review 12: CD000434.

9. Gradl G, Dietze A, Kaab M, Hopfenmuller W, Mittlmeier T (2009) Is locking of nailing of humeral head fractures superior to locking plate fixation? Clin Orthop Relat Res 467(11): 2986-2993.

10. Matziolis D, Kaeaeb M, Zaandi SS, Perka C, Greiner S (2010) Surgical treatment of two-part fractures of the proximal humeral fractures: comparison of fixed-angle plate osteosynthesis and Zifko nails. Injury 41(10): 1041-1046.

11. Smejkal K, Lochman P, Dedek T, Trlica J, Koci J (2011) Surgical treatment for proximal humerus fracture. Acta Chir Orthop Traumatol Cech 78(4): 321-327.

12. Trepat AD, Popescu D, Fernandez-Valencia JA, Cune J, Rios M, et al. (2011) Comparative study between locking plates versus proximal humeral nail for the treatment of two-part proximal humeral fractures. Eur J Orhop Surg Traumatol 22(5): 373-379.

13. Lekic N, Montero NM, Takemoto RC, Davidovitch RI, Egol KA (2012) Treatment of two-part proximal humerus fractures: intramedullary nail compared to locking plating. HSS J 8: 86-91.

14. Konrad G, Audige L, Lambert S, Hertel R, Sudkamp NP (2012) Similar outcomes for nail versus plate fixation of three-part proximal humeral fractures. Clin Orthop Relat Res 470(2): 602-609.

15. Von Ruden C, Trapp O, Hierholzer C, Prohaska S, Wurm S, et al. (2014) Intramedullary nailing vs locking plate osteosynthesis in proximal humeral fractures: Long -term outcome.

16. Gerber C, Werner CM, Vienne P (2014) Internal fixation of complex fractures of humerus. J Bone Joint Surg Br 86(6): 848-855.

17. Egol KA, Ong CC, Walsh M, Jazrawi LM, Tejwani NC, et al. (2008) Early complications in proximal humerus fractures (OTA Types 11) treated with locked plates. J Orthop Trauma 22(3): 159-164.

18. Owsley KC, Gorczyca JT (2008) Fracture displacement and screw cutout after open reduction and locked plate fixation of proximal humeral fractures [corrected]. J Bone Joint Surg Am 90(2): 233-240.

19.Xiaodong X, Dianying Z, Zhongguo F (2014) Treatment of proximal humeral fractures with interlocking intramedullary nail versus locking plate. Chin J Shoulder Elbow 2: 230-234. 
20. Boudard G, Pomares G, Milin L (2014) Locking plate fixation versus antegrade nailing of 3- and 4-part proximal humerus fractures in patients without osteoporosis. Comparative retrospective study of 63 cases. Orthop Traumatol Surg Res 100(8): 917-924.

21. Gracitelli MEC, Lobo FL, Ferreira GMA, da Palma MV, Malavolta EA, et al. (2013) Outcomes evaluation of locking plate osteosynthesis in displaced fractures of the proximal humerus. Rev Bras Ortop 48(6): 491-499.
22. Gadea F, Favard L, Boileau P (2016) Fixation of 4-part fractures of the proximal humerus: Can we identify radiological criteria that support locking plates or IM nailing? Comparative, retrospective study of 107 cases. Orthop Traumatol Surg Res 102(8): 963-970.

23. Cheng, Gang, Tao, Zhanhuai, Zhang, et al. (2016) Comparative study of locking plate and intramedullary nail in treatment of Neer III, IV proximal humerus fractures. J Med Res 45: 108-111.

For possible submissions Click below: 